\title{
OPTIMIZATION OF GUIDED DISCOVERY LEARNING MODELS TO INCREASE STUDENTS' INTEREST IN MATHEMATICS
}

\author{
Nurhayani $^{* 1}$, Raden Rosnawati ${ }^{2}$, Tuslikhatun Amimah ${ }^{3}$ \\ ${ }^{1,2,3}$ Universitas Negeri Yogyakarta
}

\section{Article Info \\ Article history:}

Received Jan 212020

Revised Jan 29, 2020

Accepted Feb 2, 2020

\section{Keywords:}

Guided discovery learning,

Learning interest,

Mathematics education

\begin{abstract}
Student interest in learning is a very important factor in determining student success in learning mathematics. Various attempts were made by educators and educational researchers to increase student interest in learning. This research is a classroom action research model by Kemmis and Mc Taggart that aims to describe the application of Guided Discovery learning in optimizing students' interest in learning mathematics. The increase in students' interest in learning mathematics is also supported by the results of student achievement. The research data consisted of students' interest in learning mathematics, learning achievement data, and observations of learning outcomes. Data on learning interest in mathematics is obtained through a questionnaire, data on learning achievement is obtained through tests and data on the results of observations of learning achievement are obtained through observation sheets during learning. In general, the results of the study showed that the average student interest in learning mathematics at 83.93 reached the good category. The completeness of student achievement test results reached $83.87 \%$ of students achieving the minimum completeness criteria with an average student score of 85.61. The percentage of teacher and student learning outcomes respectively at $83.80 \%$ and $76.91 \%$ reached the good category. Therefore it can be concluded that the Guided Discovery learning model can be applied to optimize students' interest in mathematics learning especially by paying attention to the results of reflections from this study.
\end{abstract}

Copyright $@ 2020$ IKIP Siliwangi. All rights reserved.

\section{Corresponding Author:}

Nurhayani,

Department of Mathematics Education,

Universitas Negeri Yogyakarta,

Jl. Colombo No.1, Karang Malang, Depok, Sleman, Yogyakarta 55281, Indonesia.

Email: nurhayaniyhaniuny@gmail.com

\section{How to Cite:}

Nurhayani, N., Rosnawati, R., \& Amimah, T. (2020). Optimization of guided discovery learning models to increase students' interest in mathematics. Infinity, 9(1), 69-80.

\section{INTRODUCTION}

Education is very important in the survival of life. Education can make the individual into a person of knowledge and character. Education cannot be separated from school, because in school there is a teaching and learning process that can be a provision of children's education. One of the subjects studied at school is mathematics. The role of mathematics increase in line with the development of science. Someone who understands 
and can do mathematics has the opportunity to increase significantly so that they can make their future. This opinion is in line with NCTM (2000) which revealed that someone who understands mathematics will be able to increase opportunities and choices to make their future.

However, the reality shows that there are still obstacles or problems faced by students in learning, especially learning mathematics. One of the problems currently facing our education world is the problem of poor understanding of mathematics in the learning process. In the learning process, students have less interest in learning mathematics. This can be seen from observations made by researchers in one of the schools namely in MAN 1 Yogyakarta, especially in class XI MIPA 2. Researchers observed the lack of students who have math textbooks that can be used to study mathematics. Student notes are also incomplete. When asked about the material they have recorded, not all students are able to explain back to the researcher the purpose of their notes. This also shows the lack of student attention to mathematics. In addition, student involvement in the learning process is still lacking so that student interaction is not achieved properly. This causes learning to be less meaningful and easy for students to forget. This is supported by the results of students' interest questionnaire before implementing guided discovery learning that shown in Table 1.

Table 1. Results of questionnaire students' interest before implementing guided discovery learning

\begin{tabular}{cc}
\hline Criteria & Early Mathematics Learning Interest \\
\hline Very Good & $0 \%(0$ student $)$ \\
Good & $22.58 \%(7$ student $)$ \\
Quite Good & $58.06 \%(18$ student $)$ \\
Poor & $12.90 \%(4$ student $)$ \\
Very Poor & $6.45 \%(2$ student $)$ \\
\hline
\end{tabular}

From the Table 1, we obtained information on interest in learning mathematics before implementing guided discovery learning model shows that there is not yet a student who achieved very good criteria, $22.58 \%$ or 7 students included in the good category, $58.06 \%$ or 18 students included in the quite good category, $12.90 \%$ or 4 students included in the poor category and $6.45 \%$ or 2 students included in the very poor category. So that obtained an average for initial interest of 75.93 which is included in the category is quite good. This reflects the lack of student interest in learning so that learning achievement still low.

The results of pre-research observations show that learning achievement is still low and does not meet the Minimum Completeness Criteria (MCC) set by the school. It can be shown in Table 2.

Table 2 Data of learning achievement before implementing guided discovery learning

\begin{tabular}{lc}
\hline \multicolumn{1}{c}{ Description } & Criteria \\
\hline Mean & 26 \\
Standar Deviation & 19.459 \\
Ideal Minimum Score & 0 \\
Minimum Score & 0 \\
Ideal Maximum Score & 100 \\
Maximum Score & 70
\end{tabular}


Variance

Minimum Completeness Criteria
378.667

76

From the Table 2 obtained information on students' learning achievement before implementing guided discovery learning model shows that the Mean of students' learning achievement is 26 with minimum and maximum score respectively 0 and 70 . According the table, it can be concluded that there were no students or $0 \%$ of students who achieved the Minimum Completeness Criteria $(\mathrm{MCC}=76)$.

Wibowo (2017) revealed that interest is an impulse in a person to give more attention to an object. Furthermore, Henriksen, Dillon, \& Ryder (2015) say that interest illustrates a mindset that is characterized by the need to give selective attention to something that is important to someone such as an activity, purpose, or subject. This is in accordance with the expression Elliot (Astutik, 2017) who revealed that interest is the same thing and is closely related to curiosity or interest where the characteristics are expressed by the relationship between a person and certain activities or objects. Students who have an interest in a particular subject give greater attention to the subject. This can be interpreted that if students have a high interest in mathematics it will facilitate students in learning mathematics, because their attention will tend to learn mathematics. Based on the description above, it can be concluded that interest is an attitude of awareness of each individual to do something that moves themselves because there is a sense of pleasure and interest to achieve the desired goal. The level of student interest in learning can be seen and measured by: 1) feelings like pleasure (Krapp \& Prentzel, 2011), 2) interests marked by reading and learning mathematics, learning without coercion, and recording mathematics lessons (Paszkowska-rogacz \& Y1ldiz, 2015) , 3) attention that is in the form of focus in learning mathematics (Vulperhorst, Wessels, Bakker, \& Akkerman, 2018) and 4) student involvement which includes activeness in participating in the learning process and doing assignments (Mumba, Mbewe, \& Chabalengula, 2015)

Learning outcomes that are often seen are learning achievements. Nitko \& Brookhart (2011) revealed that achievements are students' knowledge, skills and abilities that have been developed as a result of learning. The high interest in learning mathematics students will support increased student learning achievement. The same thing was expressed by Herzog, Ehlert, \& Fritz (2019) that interest has a strong positive relationship with success related to mathematics. The correlation between interests and achievements is quite high because the more people who are attracted to an object the more knowledge they obtain. Thus, learning mathematics should be able to stimulate students to gain high interest in learning mathematics and good learning achievement. Therefore, solutions are needed to realize these goals, such as the application of appropriate learning models so that students' interest in learning can increase and train students to be actively involved in the learning process. So students can build active interaction each other and eith teachers in order to build their knowledge. One model solution that allows to increase student interest in learning is guided discovery learning models.

In discovery learning, students must determine their own model used to solve problems as said by Alfieri, Brooks, Aldrich, \& Tenenbaum (2011) that "discovery learning occurs whenever the learner is not provided with the target information or conceptual understanding and must find it independently and with only the provided materials". Guided discovery is a learning model that emphasizes the activeness and involvement of students in learning. This is in line with what was expressed by Khasnis \& Aithal (2011) that guided discovery combines two strategies, namely learning to work alone and learning to work in groups in an effort to make learning more efficient for all students. Furthermore Khomsiatun \& Retnawati (2015) revealed that guided discovery 
involves a process that comes from one's own experience so that students will get as many opportunities as they can to discover for themselves the knowledge they need to master. The teacher's guidance can be done directly or poured in the form of student activity sheets.

Mulyana, Rusdi, \& Vivanti (2018) view that guided discovery will provide an opportunity for students to learn about how to find facts, concepts, and principles based on the experience they are doing directly. Students freely develop their ideas and knowledge in learning, but if there are obstacles the teacher has a role to provide assistance or guide students to find the right concepts. This is consistent with the opinion of Tran, Nguyen, Bui, \& Phan (2014) which states that,

In guided discovery, teacher give problem, provide context, necessary tools and students have opportunities to discover, solve problem. Teacher here plays a role as an encourageing, assistant man to ensure that students do not have troubles or do not perform their surveys, experiments.

According to Arends (2012) there are several steps involved in guided discovery learning, namely preparation and explanation of the discovery process, problem presentation, formulation of hypotheses, data collection to test hypotheses, formulation of test results and conclusions, as well as reflection on learning activities. Meanwhile, according to Agustyarini \& Jailani (2015), there are four stages of guided discovery namely, formulating questions, building procedures and gathering information, using procedures and information obtained in the second step, analyzing and evaluating the discovery process that has been carried out. Furthermore, Sanjaya (2008) mentions the steps of guided discovery learning methods including orientation, formulating problems, formulating hypotheses, collecting data, testing hypotheses and formulating conclusions.

Framework for thinking about the relationship between the steps of guided discovery learning and indicators of interest in learning look like the Figure 1.

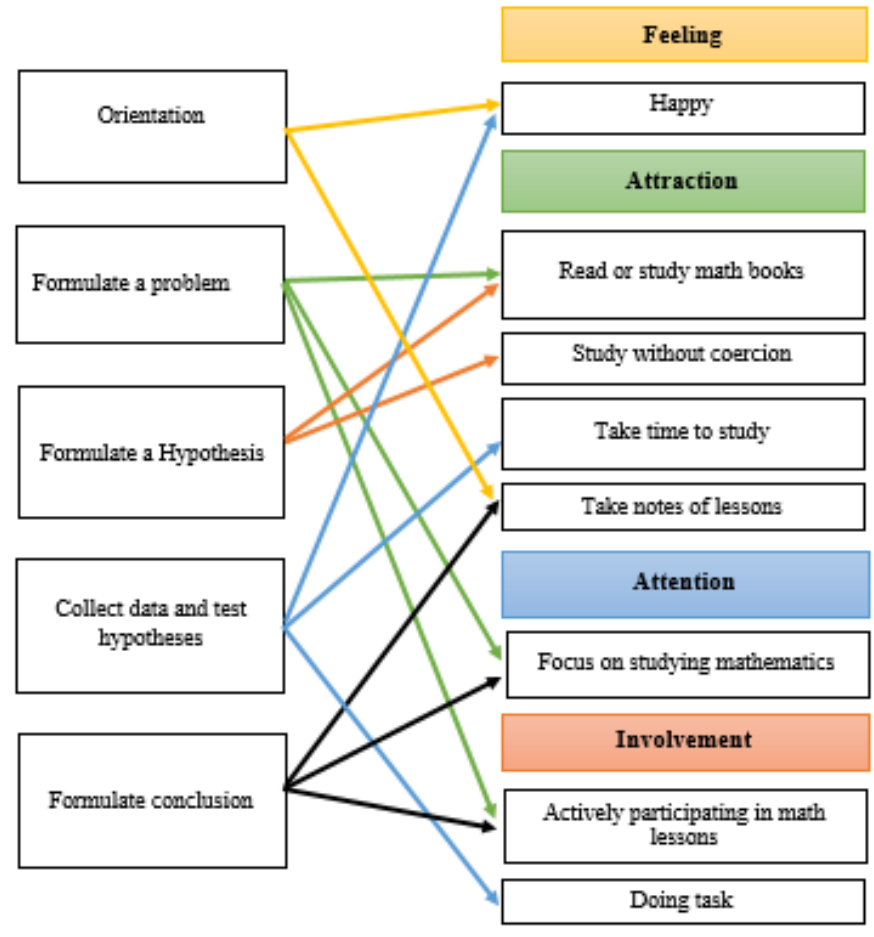

Figure 1. The linkages of the steps of guided discovery learning 
The steps of guided discovery learning models allow it to be used to optimize the aspects that exist in students' interest in learning. Like the orientation phase that is intended to foster an atmosphere of learning that is responsive can bring joy or excitement to students before starting learning. This is in line with what was expressed by Krapp \& Prentzel (2011) that the feeling of pleasure is one indicator of interest in learning, so that a high interest score indicates that students are happy when learning mathematics. The stage of formulating problems and hypotheses can stimulate students' interest and attention to read, focus on learning mathematics and be active in learning without coercion Paszkowska-rogacz \& Y1ldiz (2015). Then the stages of collecting data and testing hypotheses allow students to feel happy and can encourage students to learn and practice more to solve the given problem. This stage encourages students to interact with assignments so as to increase student interest in learning. This is supported by the statement of Habig et al. (2018) which says that the assignments given to students create interactions between assignments and students that are able to increase student interest in learning. Next to the final stage, namely formulating conclusions can stimulate students to focus, record all lessons learned and be active in taking part in expressing opinions or answers obtained by Mumba et al. (2015). Thus, the relationship between these variables is expected to increase students' interest in learning mathematics.

\section{METHOD}

This research is a class action research conducted in class XI MIPA 2 MAN 1 Yogyakarta which is located at J1. C. Simanjuntak No. 60, Terban, Kota Yogyakarta. This research was conducted in mathematics with trigonometry material in odd semester 2019/2020 school year.

This research was conducted in two cycles. The purpose of classroom action research is an effort to improve teaching practices through the provision of actions in class that begin with lesson plans followed by actions and observations in class as well as reflections on these actions. The implementation of this study was designed to follow the Kemmis and Mc Taggart planning models, namely, planning, implementing actions, observing and reflecting. The next cycle is based on the results of reflection.

The data in this study consisted of learning achievement data, students' interest in learning mathematics, and observations of learning outcomes. Data from observations of the implementation of learning contain activities during the teaching of mathematics obtained through observation sheets when implementing actions and analyzed descriptively during reflection. Learning achievement data was obtained through tests on trigonometric material and students' mathematics learning interest data were obtained through a questionnaire with four indicators namely feeling, attraction, attention and involvement.

Validity test used in this study uses the Product Moment Correlation formula:

$$
r_{x y}=\frac{N \sum X Y-\left(\sum X\right)\left(\sum Y\right)}{\sqrt{\left\{n \sum X^{2}-\left(\sum X\right)^{2}\right\}\left\{n \sum Y^{2}-\left(\sum Y\right)^{2}\right\}}}
$$

$\begin{array}{ll}r_{x y} & =\text { correlation coefficient betwen variable } \mathrm{X} \text { dan Variable } \mathrm{Y} \\ N \sum X Y & =\text { the number of multiplications between variable } \mathrm{X} \text { dan variable } \mathrm{Y}\end{array}$ 
$\begin{array}{ll}\sum X & =\text { number of variables } \mathrm{X} \\ \sum Y & =\text { number of variables } \mathrm{Y}\end{array}$

From the results of the validity test using SPSS 21 as many as 31 respondents who answered 25 questionnaires from the total questionnaire given to respondents included in the valid category so that there were no questionnaires that needed to be deleted (a) as shown in the Table 3.

Table 3 Validity Test Results

\begin{tabular}{clcc}
\hline & & $\mathrm{N}$ & $\%$ \\
\hline \multirow{6}{*}{ Cases } & Valid & 31 & 100 \\
& Excluded $^{\mathrm{a}}$ & 0 & 0 \\
& Total & 31 & 100 \\
\hline
\end{tabular}

Based on the Table 3, it can be concluded that the learning interest questionnaire used in this study is valid. As for the reliability coefficient estimation used the alpha croncbach formula with the following formula.

$$
\alpha=\left(\frac{p}{p-1}\right)\left(1-\frac{\sum_{i=1}^{p} \sigma_{y_{i}}^{2}}{\sigma_{x}^{2}}\right)
$$

Information:

$$
\begin{array}{ll}
\alpha & =\text { reliability sought } \\
p & =\text { Number of questionnaires tested } \\
\sum_{i=1}^{p} \sigma_{y_{i}}^{2} & =\text { Number of variance scores per questionnaire } \\
\sigma_{x}^{2} & =\text { total variance }
\end{array}
$$

The reliability test results are shown in the Table 4 .

Table 4 Reliability Test Results

\begin{tabular}{cc}
\hline Cronbach's Alpha & N of Items \\
\hline 0.823 & 31 \\
\hline
\end{tabular}

Based on the results of the reliability test using SPSS 21 (Table 4) as indicated in the table above, obtained a significant Alpha Cronbach value of 0.823. This means that the learning interest questionnaire used is included in the reliable category.

There are several indicators of success used in this study, including indicators of success in learning interest, indicators of success in learning achievement and indicators of learning accomplishment. This study was successful if the average student interest in learning was included in either category with an interval value $(X)$ of $83.3<X \leq 100$, students who achieved mastery learning achievement reached a minimum of $75 \%$, and the implementation of learning reached a good category with a percentage $(\mathrm{P})$ which is $65 \%<$ $\mathrm{P} \leq 85 \%$.

\section{RESULTS AND DISCUSSION}

\subsection{Cycle I}


The first cycle carried out four meetings which began from 7, 8, 14 and 15 October 2019. There are two core materials that students learn about simple trigonometric equations and trigonometric equations in the form of quadratic equations.

Based on the data obtained, observations of the implementation of guided discovery learning by the teacher in the first cycle are in the good category with a percentage of $77.14 \%$. This shows that the implementation of guided discovery learning by the teacher in the first cycle has reached the predetermined indicator that is $\geq 75 \%$. The observation of the implementation of guided discovery learning by students in the first cycle is in the quite good category with a percentage of $60 \%$. This shows that the implementation of guided discovery learning by students in the first cycle has not reached the predetermined indicator that is $\geq 75 \%$.

The results of the student interest in learning mathematics questionnaire at the end of the first cycle are shown in Table 5.

Table 5 Results of questionnaire students' interest in cycle I

\begin{tabular}{cc}
\hline Criteria & Mathematics Learning Interest Cycle I \\
\hline Very Good & $0 \%(0$ student $)$ \\
Good & $38.7 \%(12$ student $)$ \\
Quite Good & $51.61 \%(16$ student $)$ \\
Poor & $9.67 \%(3$ student $)$ \\
Very Poor & $0 \%(0$ student $)$ \\
\hline
\end{tabular}

From the Table 5, information obtained on the results of the interest in learning mathematics after the implementation of guided discovery learning in cycle I, there were no students in the excellent category, amounting to $38.7 \%$ or 12 students included in the good category, amounting to $51.61 \%$ or 16 students included in the good enough category, amounting to 9.67 or 3 students fall into the unfavorable category, and there are no students whose interest in learning mathematics is included in the very poor category. In order to obtain an average student interest in learning for cycle 1 of 79.35 which is included in the quite good category. One indicator of success in this study, said to be successful if the average student interest in learning is included in either category with an interval value $(\mathrm{X})$ that is $83.3<\mathrm{X} \leq 100$. Because the average value of students 'interest in learning for cycle 1 is 79.35 , the results of students' interest in learning show that they have not been successful or have not met the specified success indicators.

The percentage of learning achievement after the guided discovery model applied in cycle 1 was $51.61 \%$ or 16 students reached MCC and $48.38 \%$ or 15 students who have not yet reached the MCC with an average student score of 71.29. Indicators of success from the results of learning achievement are said to be successful if the student score reaches the completeness of learning achievement reaches a minimum of $75 \%$. However, because the results of learning achievement in cycle 1 showed only $51.61 \%$ or 16 students reached MCC, the results of student achievement showed not successful or did not meet the specified success indicators. The learning implementation data reached a good category with a percentage $(\mathrm{P})$ that is $65 \%<\mathrm{P} \leq 85 \%$.

In the learning process that has been carried out, it is stated several things that have not been carried out in accordance with the mindset chart designed by the researcher at the outset. The teacher starts the lesson by praying and checking student attendance. The teacher then gives apperception to students and conveys the material to be studied as well as a brief explanation that can lead students to solve the problems given in the worksheet. 
In the learning process students learn by group settings. There are 6 groups formed consisting of 5-6 students per group. This group division is done randomly. Each group is given a worksheet that contains problems related to trigonometric equations. At the orientation stage, namely the granting of apperception, the majority of students still did not show excitement because the responses given by students were still lacking. Students also do not record fully what is conveyed by the teacher. Then in the stage of formulating the problem and formulating a hypothesis, only some members of the group are actively involved to understand the problem given which shows that students' interest is still lacking. This is in line with what was delivered by Rautiainen, Mäensivu, \& Nikkola (2018) which revealed that students who pay attention to lessons and are actively involved in the lessons indicate that these students have high learning interest and vice versa. When learning in class, most students are still confused to develop their way of thinking to solve the problems presented. Therefore, the teacher gives limited direction, but apparently students are still having difficulties. This causes the direction of the teacher still dominates the learning process compared to the activeness of students in developing their way of thinking.

At the stage of formulating conclusions, the teacher tries to encourage students to present their findings in front of the class, but student participation is still lacking. The student representatives who wrote the answers on the board, were still constrained in explaining what they had written. In addition, other students have not fully focused on listening to what their peers say. This indicates that the stages of the guided discovery model have not fully stimulated students' interest in learning. Based on the results of cycle 1 , it is necessary to do further learning in cycle II.

\subsection{Cycle II}

The second cycle carried out four meetings which began on 28, 29 October, 7 and 11 November 2019. In cycle II, the material students learned was analytic trigonometry. Based on the data obtained, the results of students' interest in learning mathematics at the end of the second cycle are shown in Table 6.

Table 6. Results of questionnaire students' interest in cycle II

\begin{tabular}{cc}
\hline Criteria & Mathematics Learning Interest Cycle II \\
\hline Very Good & $9.67 \%(3$ student $)$ \\
Good & $41.93 \%(13$ student $)$ \\
Quite Good & $48.38 \%(15$ student $)$ \\
Poor & $0 \%(0$ student $)$ \\
Very Poor & $0 \%(0$ student $)$ \\
\hline
\end{tabular}

Based on the Table 6 obtained information about the percentage of interest in learning mathematics after the application of guided discovery learning in cycle II, namely $9.67 \%$ or 3 students achieving very good criteria, $41.93 \%$ or 13 students achieving good criteria, $48.38 \%$ or 15 students achieving the criteria quite good, and already none of the students achieved the criteria for being either poor or very poor. The conditions of students' interest in learning cycle I and cycle II as a whole are shown in Figure 2. 


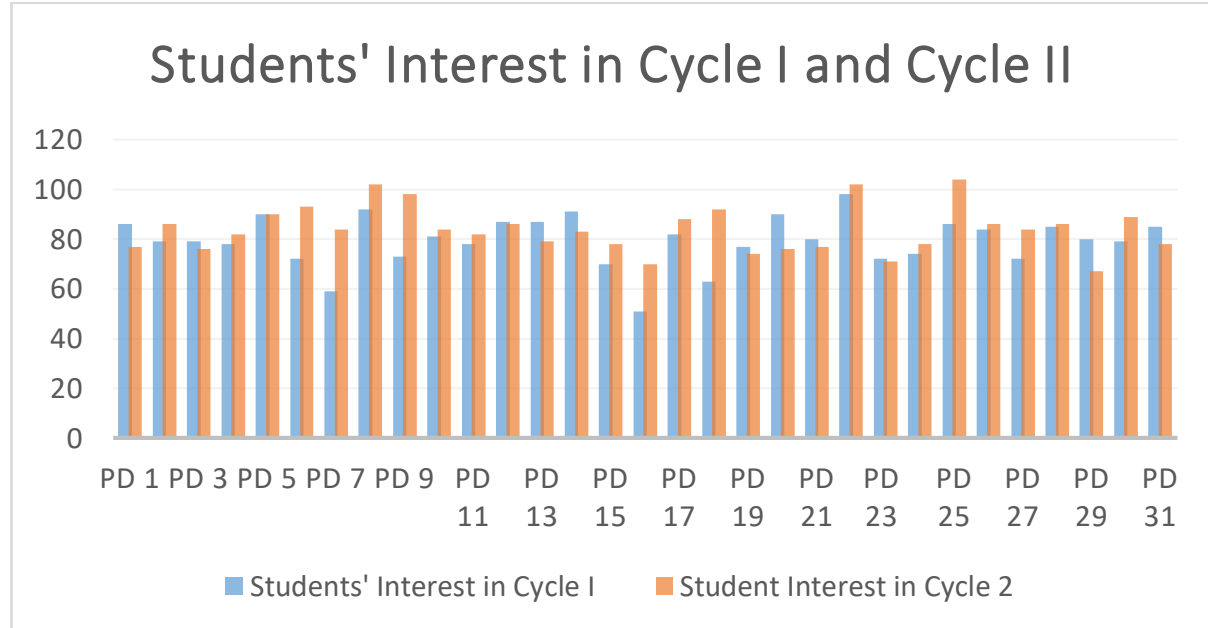

Figure 2. Conditions of student interest in cycle 1 and cycle 2

From the Figure 2, it appears that the conditions of student interest in learning individually in cycle I and cycle II. Although not all students experience an increase in learning interest from cycle I to cycle II as happened to the first, third, twelfth, thirteenth and other students, but overall the average student interest in learning for cycle II has reached 83.93. This shows that the results of students'interest in learning have reached the specified indicators of success. The conditions of students for learning achievement results are shown in the Figure 3.

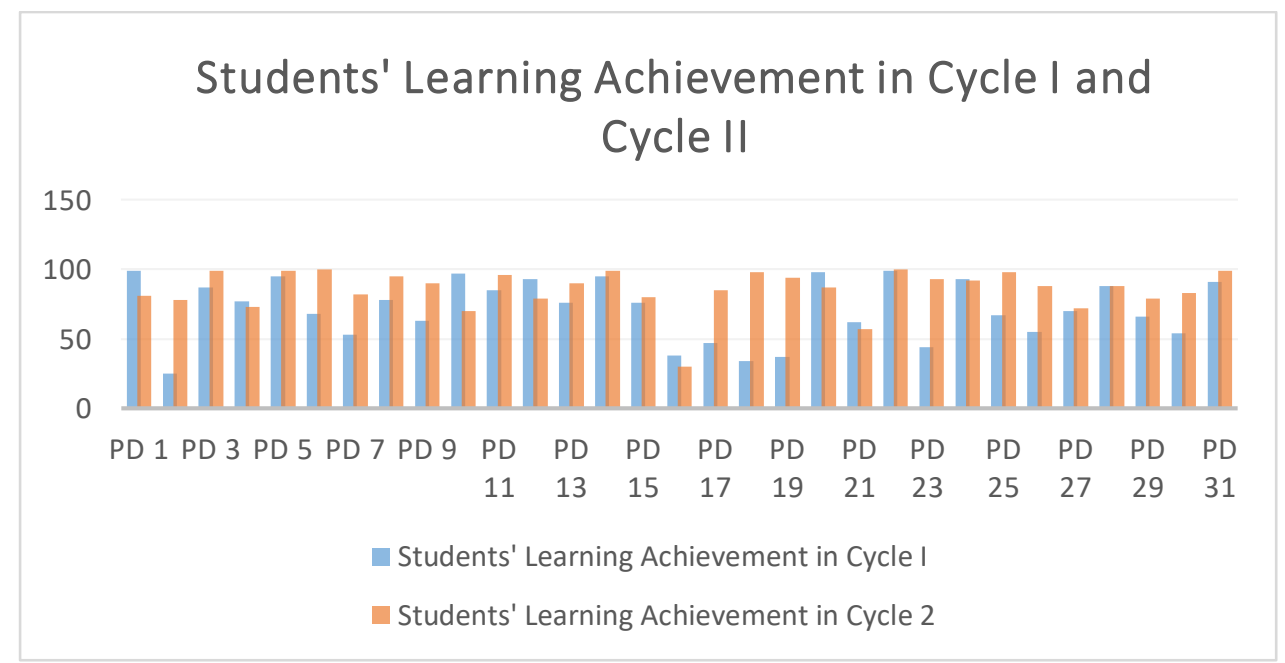

Figure 3. Conditions of students' learning achievement in cycle 1 and cycle 2

Figure 3 show that not all students have increased learning achievement. This is shown by the first, third, ninth, twelfth, and other students, but overall the percentage of learning achievement obtained by students after the guided discovery model has been applied in the cycle II has reached $83.87 \%$ or as many as 26 students have achieved MCC and the remaining $16.12 \%$ or 5 students have not yet reached the MCC with an average student score of 85.61. This shows that the mastery of learning achievement has reached the specified indicator.

Observations on the implementation of guided discovery learning by the teacher in the second cycle are in the good category with a percentage of $83.80 \%$. This shows that the implementation of guided discovery learning by the teacher in the second cycle has 
reached the specified indicator that is $\geq 75 \%$. Observations on the implementation of guided discovery learning by students in the second cycle are also already in the good category with a percentage of $76.19 \%$. This shows that the implementation of guided discovery learning model by students in the second cycle also has reached the specified indicator that is $\geq 75 \%$.

Based on the data obtained, the average learning interest of students is 83.93 which is included in either category, the percentage of student achievement is $83.87 \%$ or as many as 26 students have succeeded in achieving the minimum completeness criteria, and the percentage of student and teacher learning outcomes respectively $83.80 \%$ and $76.91 \%$ have achieved good criteria.

In process learning, the teacher opens the lesson by praying and checking student attendance. The teacher then gives apperception to the students and tries to ask some questions about the material that has been given in cycle I. After that the teacher then gives motivation and advice to be more earnest in learning, because understanding the material taught will really help them to understand the next material, considering that trigonometry material is a fairly dense and continuous material. In contrast to during the first cycle, this time the students in the class began to respond by giving questions to the teacher, the interaction was already more visible.

Group settings are no longer done in this second cycle. The teacher tries to use power point media to make it easy to present problems that will be solved by students. The teacher emphasizes that each student will be called randomly to present the results of their work. The class conditions began to be active which indicates student interest in learning is better than before. This is in line with what was expressed by Rautiainen et al. (2018) who revealed that students who pay attention to lessons and are actively involved in learning indicate that these students have a high interest in learning. The teacher then asks each student to prepare a notebook and asks students to write down and formulate problems and hypotheses of the problems presented. Students seem more excited and interact with each other to exchange opinions.

Stage of collecting and testing hypotheses, the teacher goes around observing students. Some students who experience obstacles start to build interaction with the teacher by confirming their answers, those who ask questions they don't understand. After the work time is up, the teacher checks by asking students who have finished working to raise their hands. In this case there are still some students who have not been able to solve the problems given, especially the male students. The teacher then provides assistance to students who have not yet finished and provokes other students who dare to write and explain their answers without being appointed in front of the blackboard. Some students began to dare to raise their hands and come forward to present the results of their work. After that the teacher asks other friends to respond and ask questions they don't understand. At the end of the lesson the teacher corrects if there are errors and gives reinforcement to the concepts of the material that have been learned so that the understanding of the concepts obtained by students is not wrong. This is in accordance with the opinion of Kirschner, Sweller \& Clark (2006) who view that the learning process must be guided by the teacher so that students get the right understanding of concepts.

The teacher appreciates any progress made by students by asking other friends to give applause to friends who dare to present their work in front of the blackboard. Students also looked happy, especially those who managed to solve the problem and who were given an appreciation by their friends for daring to present the results of their work. According the explanantion above, it can be concluded that in cycle II the overall indicators of success from this study have been achieved. 


\section{CONCLUSION}

After carrying out learning for two cycles, In cycle I we obtain average students' interest is 79.35 which is included in the quite good category and have not met the specified success indicators. The average student interest in learning for cycle II has reached 83.93. This shows that the results of interest in learning have reached the specified success indicators. The results of learning achievement in cycle 1 showed only $51.61 \%$ or 16 students reached MCC, It showed not successful or have not met the specified success indicators. In cycle II, the results of learning achievement has reached $83.87 \%$ or as many as 26 students have achieved MCC and the remaining $16.12 \%$ or 5 students have not yet reached the MCC with an average student score of 85.61. This shows that the mastery of learning achievement has reached the specified indicator. Observations on the implementation of guided discovery learning by the teacher and students in cycle I rescpectively are $77.14 \%$ and $60 \%$. This shows that. it has not met the specified success indicators. In cycle II, observations on the implementation of guided discovery learning by the teacher and students in cycle I rescpectively are $83.80 \%$ and $76.19 \%$. This shows that the implementation of guided discovery learning model by teacher and students in cycle II also has reached the specified indicator that is $\geq 75$. According the result of this research, it appears that the interrelationships between the guided discovery learning model and learning interest, it is found that the steps in the guided discovery learning model can be used to optimize aspects of student interest in learning. So it can be concluded that the application of guided discovery learning can be used to optimize students' interest in learning mathematics.

\section{REFERENCES}

Agustyarini, Y., \& Jailani, J. (2015). Pengembangan bahan ajar matematika dengan pendekatan kontekstual dan metode penemuan terbimbing untuk meningkatkan eq dan sq siswa smp akselerasi. Jurnal Riset Pendidikan Matematika, 2(1), 135-147. https://doi.org/10.21831/jrpm.v2i1.7156

Alfieri, L., Brooks, P. J., Aldrich, N. J., \& Tenenbaum, H. R. (2011). Does discoverybased instruction enhance learning? Journal of Educational Psychology, 103(1), 118. https://doi.org/10.1037/a0021017

Arends, R. I. (2012). Learning to teach (Ninth Edition). New York: McGraw-Hill.

Astutik, H. S. (2017). Keefektifan pembelajaran berdasarkan masalah pada bangun ruang sisi datar ditinjau dari penguasaan sk, motivasi, dan minat siswa SMP. Jurnal Riset Pendidikan Matematika, 4(1), 56-66. https://doi.org/10.21831/jrpm.v4i1.12722

Habig, S., Blankenburg, J., Vorst, H. V., Fechner, S., Parchmann, I \& Sumfleth, E. (2018). Context characteristics and their effects on students' situational interest in chemistry. International Journal of Science Education. Retrieved from https://doi.org/10.1080/09500693.2018.1470349

Henriksen, E. K., Dillon, J., \& Ryder, J. (2015). Understanding student participation and choice in science and technology education. (E. K. Henriksen, J. Ryder, \& J. Dillon, Eds.). London: Springer. https://doi.org/10.1007/978-94-007-7793-4 
Herzog, M., Ehlert, A., \& Fritz, A. (2019). Development of a sustainable place value understanding. In International Handbook of Mathematical Learning Difficulties, 561-579. https://doi.org/10.1007/978-3-319-97148-3_33

Khasnis, B. Y., \& Aithal, M. (2011). Guided discovery method: a remedial measure in mathematics. International Reffered Research Journal, 2(22), 21-22.

Khomsiatun, S., \& Retnawati, H. (2015). Pengembangan perangkat pembelajaran dengan penemuan terbimbing untuk meningkatkan kemampuan pemecahan masalah. Jurnal Riset Pendidikan Matematika, 2(1), 92-106. https://doi.org/10.21831/jrpm.v2i1.7153

Kirschner, P., Sweller, J., \& Clark, R. E. (2006). Why minimal guidance during instruction does not work: an analysis of the failure of constructivist, discovery, problembased, experiential, and inquiry-based teaching. Educational Psychologist, 41(2), 75-86. https://doi.org/10.1207/s15326985ep4102_1

Krapp, A., \& Prenzel, M. (2011). Research on interest in science: Theories, methods, and findings. International Journal of Science Education, 33(1), 27-50. Retrieved from http://dx.doi.org/10.1080/09500693.2010.518645

Mulyana, S., Rusdi, R., \& Vivanti, D. (2018). The Effect of Guided Inquiry Learning Model and Scientific Performance on Student Learning Outcomes. Indonesian Journal of Science and Education, 2(1), 105-109. https://doi.org/10.31002/ijose.v2i1.596

Mumba, F., Mbewe, S., \& Chabalengula, V. M. (2015). Elementary school teachers' familiarity, conceptual knowledge, and interest in light. International Journal of Science Education, 37(2), 185-209. https://doi.org/10.1080/09500693.2014.971906

NCTM. (2000). Principles and standards for school mathematics. United States of America: The National Council of Teachers of Mathematics.

Nitko, A. J., \& Brookhart, S. M. (2011). Educational assessment of students. Pearson. Retrieved from https://files.pearsoned.de/inf/ext/9781292054643\%0Awww.pearsoned.co.uk

Paszkowska-rogacz, A., \& Y1ld1z, D. A. (2015). Career counselling involving work with parents. Training book for career counsellors. Łódź, Poland: FAMICO.

Rautiainen, M., Mäensivu, M., \& Nikkola, T. (2018). Becoming interested during teacher education. European Journal of Teacher Education, 41(4), 418-432. https://doi.org/10.1080/02619768.2018.1462329

Sanjaya, W. (2008). Strategi pembelajaran berorientasi standar proses pendidikan. Jakarta: kencana prenada media group.

Tran, T., Nguyen, N. G., Bui, M. D., \& Phan, A. H. (2014). Discovery learning with the help of the geogebra dynamic geometry software. International Journal of Learning, Teaching and Educational Research, 7(1), 44-57.

Vulperhorst, J. P., Wessels, K. R., Bakker, A., \& Akkerman, S. F. (2018). How do STEMinterested students pursue multiple interests in their higher educational choice? International Journal of Science Education, 40(8), 828-846. https://doi.org/10.1080/09500693.2018.1452306 
Wibowo, A. (2017). Pengaruh pendekatan pembelajaran matematika realistik dan saintifik terhadap prestasi belajar, kemampuan penalaran matematis dan minat belajar. Jurnal Riset Pendidikan Matematika, 4(1), 1-10. https://doi.org/10.21831/jrpm.v4i1.10066 